\title{
Ekolojik Sistem Kuramı Çerçevesinden Ebeveyn Yabancılaşmasına Genel Bir Bakış
}

\section{An Overview of Parental Alienation from the Framework of Ecological Systems Theory}

\author{
Raziye Yüksel Doğan 10 , Çiğdem Aytekin '(D)
}

\begin{abstract}
Öz
Boşanma, kısaca, eşler arasında evliliğin hukuki açıdan sona erdirilmesi olarak tanımlanabilir. Çatışmalı ayrılık veya boşanma davalarında, ebeveynlerden birinin öfke/kızgınlık hissiyle birllikte sözleri, davranışları ve tutumlarılla diğer ebeveyni kötülemesi, çocuklarının bu ebeveyniyle olan kişisel görüşme haklarını engellemesi sonucunda çocuklar, hedefteki ebeveyne karşı yabancılaşma geliştirebilmektedir. Alanyazında ebeveyn yabancılaşması (ebeveyne yabancılaşma sendromu), özellikle yüksek çatışmalı boşanma davalarında çocukların ebeveynlerinden biriyle (yabancılaştıran ebeveyn) güçlü bir şekilde ittifak kurması ve herhangi bir meşru gerekçe olmaksızın diğer ebeveyniyle (hedefteki veya yabancılaşlan ebeveyn) ilişki kurmayı reddetmesiyle sonuçlanan dinamik bir süreç olarak kavramsallaştırılmakta ve çocuklar açısından bu sürecin duygusal istismarın bir türü olduğu belirtilmektedir. Bu derlemede ebeveyn yabancılaşması sürecinde etkili olabileceği düşünülen faktörlerin dinamik etkileşimlerinin ekolojik sistem kuramı perspektifiyle gözden geçirilmesi amaçlanmıştır. Bu kapsamda çalışmada, ebeveyn yabancılaşması kavramının genel özellikleri üzerinde durulmuş ve her bir sistem düzeyinde (mikrosistem, mezosistem, ekzosistem, makrosistem, kronosistem) ebeveyne yabancılaşma sürecini etkileyebilecek risk faktörleri ile yabancılaşmanın çocuk üzerindeki genel etkileri gözden geçirilmiş̧ir.
\end{abstract}

Anahtar sözcükler: Boşanma, çaıışmalı boşanma, ebeveyn yabancılaşması, ebeveyne yabancılaşma sendromu, ekolojik sistem kuramı, çocuk

\section{Abstract}

Divorce, in brief, can be described as the legal dissolution of marriage between the spouses. High-conflict divorce or parental separation, the children might be able to develop an alienation state towards the targeted parent because of a parent's denigration against the other one through his/her words, behaviors, and attitudes with rage/anger, and by being precluded from the rights of personal contact with that parent. Literature on divorce, parental alienation (parental alienation syndrome) is conceptualized as a dynamic process resulting in forming a strong alliance with one of the childrens' parents (alienating parent) and the denial of communication with the other parent (the targeted or the alienated parent) without any legitimate reason especially in highconflict divorce suits and It is indicated that the process is a type of emotional abuse for the children. The goal of this paper is to review the dynamic interactions of the factors which are considered effective during the parental alienation process from the ecological system theory perspective. The general specifications of the parental alienation concept are emphasized and the common effects of the alienation on the children with the risk factors that might affect the parental alienation process in each system level (microsystem, mesosystem, exosystem, macrosystem, chronosystem) are examined.

Keywords: Divorce, high-conflict divorce, parental alienation, parental alienation syndrome, ecological system theory, children

'Hacettepe Üniversitesi, Ankara, Türkiye

$凶$ Raziye Yüksel Doğan, Hacettepe Üniversitesi, Sağık Bilimleri Fakültesi, Çocuk Gelişimi Bölümü, Ankara, Türkiye raziye.yuksel@hacettepe.edu.tr| 0000-0002-9620-9081

Geliş tarihi/Received: 17.11.2020 | Kabul tarihi/Accepted: 17.03.2021 | Çevrimiçi yayın/Published online: 03.06 .2021 
BOŞANMA hukuki açıdan evlilik sözleşmesinin sonra ermesiyle sonuçlanan, psikolojik açıdan ailenin bölünmesine ya da dağılmasına neden olan ve tüm aile üyelerini etkileyebilen karmaşık bir süreç olarak tanımlanabilir (Yörükoğlu 2012). Son yıllarda, ülkemizde boşanma oranları giderek artmaktadır. Türkiye İstatistik Kurumu Evlenme ve Boşanma İstatistikleri incelendiğinde, son on yılda boşanan çiftlerin sayısının \%30,7 oranında arttığı, 2010 yılında 118 bin 568 çiftin, 2019 yılında 155 bin 47 çiftin boşandığı ve 2019 yılı içinde gerçekleşen boşanma olaylarından 139 bin 660 çocuğun etkilendiği görülmektedir (TÜİK 2019). Boşanma oranlarının artmasında ise, toplumsal ve kültürel değişimler ve bu değişimlerin aile yaşantısına olan yansımalarının etkili olduğu belirtilebilir (Doğan 1998, Steinberger 2006, Aydın ve Baran 2010, Bolhari ve ark. 2012, Şen 2015).

Boşama sonrasında ebeveynler, aralarındaki partner ilişkisinden bağımsız olarak ebeveyn rol ve sorumluluklarını yeniden düzenlediği yeni bir aile dinamiği oluşturmaktadır. $\mathrm{Bu}$ noktada boşanmanın, aile yapısı üzerinde psikolojik, ekonomik ve sosyal açıdan birtakım değişimleri de beraberinde getirdiği ifade edilebilir (Emery 2011, Güler 2017). Araştırmalar, boşanma sonrasında çiftlerin \%75 ile \%80'inin boşanmayı takiben iki ile üç yıllık bir süre içerisinde, çekirdek aileden iki çekirdekli bir aile yapısına başarıyla geçiş yapabildiğini göstermektedir (Hetherington ve Kelly 2002). Boşanma sonrası sürece uyum sağlayabilen ebeveynler; duyarlı ve işlevsel ebeveynlik, transaksiyonel kalıplar ve sınırlar çerçevesinde çocuklarıyla sağlıklı bir biçimde ilişkilerini sürdürebilmektedir (Polak ve Saini 2015). Ancak alanyazında, boşanma sonrası uyum sürecinin zor ve zaman alıcı olabildiği, çiftlerin bu süreçte öfke, incinme, kırgınlık, suçluluk gibi duyguları art arda yaşayabildiği belirtilmektedir (Tein ve ark. 2000, Pines ve ark. 2002, Zafar ve Kausar 2014). Boylamsal araştırmalar, boşanan çiftlerin yaklaşık \%10 ile \%15'inin iki ile üç yıl sonrasında da devam eden “yüksek çatışma” içerisinde kalabildiğini göstermektedir (Maccoby ve Mnookin 1992, Johnston 1994, Johnston ve ark. 2009). Yüksek çatışma kavramı; eşler arasında çatışmaların sıklığı, süresi ve yoğunluğu dikkate alındığında, bireyler veya diğer aile üyeleri (özellikle çocuklar) için olumsuz etkilere neden olabilecek çiftleri ifade etmek için kullanılmaktadır (Cummings ve Davies 1994).

Ebeveynler arasında devam eden çatışmalara bağlı olarak, bir ebeveynin diğerine karşı gözlemlenebilen olumsuz tutumları çocukların da ebeveynlerine yönelik algılarını önemli düzeyde etkileyebilmektedir (Moné ve Biringen 2012). Alanyazında, boşanan ebeveynlerin birbirine ve çocuklarına karşı tutum ve davranışlarının çocuklar üzerinde önemli bir etkiye sahip olduğu; ebeveyn çatı̧̧masından etkilenen çocukların, kişiler arası ilişkiler, akademik başarı, psikolojik ve sosyal uyum gibi birçok farklı alanda çeşitli sorunlarla karşılaşabildiği belirtilmektedir (Gregory Öngider 2016). Boşanma süreci ve sonrasında ebeveynler arasındaki yüksek çatışmanın ortasında kalan çocuklar tarafindan bu süreç, savaş bölgesinin ortasında yaşamaya benzetilebilmektedir (Ordway ve ark. 2020). Bu çerçevede, çiftlerin evlilik birliğini sonlandırmalarına rağmen çatışmalı ilişkiyi sürdürmeye devam etmeleri durumu, çeşitli açılardan çocuklar üzerinde olumsuz etkilere neden olabilmektedir (Karataş 2019). Ayrıca bu süreçte, duygusal, psikolojik ve ekonomik açıdan çeşitli zorluklar yaşayan ebeveynlerin ilgilerini kendilerine yöneltebildiği ve ilişkilerinde bitmeyen çatı̧maları 
çocukları üzerinden de devam ettirebildiği de görülmektedir (Şen 2015). Bazı koşullarda ebeveynlerden biri sözleri, davranışları ve tutumlarıyla çocuğu diğer ebeveynine karşı kötüleme girişiminde bulunabilmektedir (Kelly ve Johnston 2001). Bu durum çocuğun ebeveynine yönelik olumsuz duygular hissetmesine, ebeveyniyle görüşmek istememesine, ebeveyniyle iletişim kurmayı reddetmesine neden olabilmektedir (Kelly ve Johnston 2001, Kayma Güneş 2007, Koçyıldırım 2010). Boşanma sürecinde ebeveyn reddi, normal ya da kabul edilebilir nedenlerden ötürü ortaya çıkabileceği gibi bir yabancılaşma durumu söz konusu olduğunda da ortaya çıkabilmektedir (Güler 2017). Özellikle çatışmalı boşanma sürecinde kabul edilebilir bir gerekçe olmaksızın çocuğun ebeveynlerinden birini tercih ederek diğer ebeveyniyle ilişki kurmayı reddetmesi, görüşmeye direnç göstermesi ve yabancılaşmı̧̧ davranışlar sergilemesi durumuyla karşılaşan ruh sağllğ̣ profesyonellerinin klinik gözlemleri doğrultusunda ebeveyne yabancılaşma kavramı literatürde incelenmeye başlanmıştır (Wallerstein ve Kelly 1976, Gardner 1985, Gardner 1998, Gardner 2002, Gardner 2004a, Gardner 2004b). Tarihsel süreçte ebeveyn yabancılaşması kavramının farklı araştırmacılar tarafindan patolojik yabancılaşma (Wallerstein ve Kelly 1976), ebeveyne yabancılaşma sendromu-EYS (Gardner 1985), yabancılaşan çocuk (Kelly ve Johnston 2001), haksız/gerekçesiz reddedilme (Fidler ve ark. 2013), ebeveyn yabancılaşması (Darnall 2010) gibi farklı isimlerle tanımlandığı, terime yönelik çeşitli olgu örneklerinin yayınlandığı ve bilimsel araştırmaların yapıldı̆̆ı görülmektedir.

$\mathrm{Bu}$ derlemenin amacı, ebeveyn yabancılaşması sürecinde etkili olabileceği düşünülen faktörlerin dinamik etkileşimlerini, ekolojik sistem kuramı perspektifiyle gözden geçirmektir. Bu kapsamda makalede, ebeveyn yabancılaşmasının tarihsel gelişimi ve kavrama yönelik güncel tartışmalara genel olarak değinilerek, her bir sistem düzeyinde (mikrosistem, mezosistem, ekzosistem, makrosistem, kronosistem) ebeveyne yabancilaşma sürecini etkileyebilecek risk faktörleri ve yabancılaşmanın çocuk üzerindeki genel etkileri gözden geçirilecektir.

\section{Ebeveyn yabancılaşma sendromu kavramı}

Ebeveyn yabancılaşmasının literatürde tanımlanmasıyla birlikte, kavramın yapısal olarak geçerliğine ve hukuk alanında kullanımına ilişkin tartışmaların da söz konusu olduğu görülmektedir (Johnston ve Sullivan 2020). Tarihsel olarak bakıldığında, ebeveyn yabancılaşmasının izlerinin Yunan Mitolojisine dayandırıldığı görülse de (Torun 2011, Yvanna Aires Gadelha 2016, Kirc1 ve ark. 2017, Torun 2017) alanyazında ebeveyn yabancılaşması davranışlarının, ilk olarak psikanalist Wilhelm Reich tarafından tanımlandığı belirtilmektedir (Reich 1949). Wilhelm Reich, bazı kişilik özelliklerine sahip ebeveynlerin, boşanma sürecinde oluşabilecek narsistik yaralanmaya karşı kendilerini korumak için eski eşlerini kötülediğini ve velayet konusunda eşleriyle çatışma yaşadığını iddia etmiştir (Bernet 2008). İlerleyen süreçte Wallerstein ve Kelly (1976), boşanma sonrasında çocuğun ebeveynini reddetmesi veya ebeveyniyle görüşmek istememesi konusundaki direncini patolojik yabancılaşma durumu olarak değerlendirmiş ve bazen çocukların ebeveynlerinden birinin tarafını tutarken diğerine karşı cephe alabileceğini belirtmiştir. 
1980’li yıllarda Richard Gardner boşanmakta olan, boşanmı̧ ebeveynler ve çocuklar üzerinde yapmış olduğu gözlemlerinden yola çıkarak, özellikle çatışmalı boşanma davalarında ebeveynlerden birinin diğer ebeveyni kötülemesi sonucunda çocuğun kötülenen ebeveynden uzaklaşması durumunu açıklamak için "[ebeveyne yabancılaşma sendromu (EYS)]” terimini kullanmıştır. EYS'yi; herhangi bir meşru gerekçe olmaksızın çocuğun ebeveynlerinden birinin (yabancılaştıran ebeveyn) etkisinden dolayı, diğer ebeveyniyle (hedefteki ebeveyn) ilişki kurmayı reddettiği zihinsel bir durum olarak tanımlamıştır (Gardner 1985). Çocukta, sekiz farklı davranışsal semptomun gözlenmesi (hedefteki ebeveyni kötüleyerek ebeveyne yönelik yürütülen iftira kampanyasına ortak olma, hedefteki ebeveyni reddetmek için zayıf, tutarsız ve anlamsız açıklamalarda bulunma, bağımsız düşünür fenomeni, ambivalan duyguların eksikliği, ödünç alınan senaryoların varlığı, çocukta gözle görülebilir bir suçluluğun olmaması, hedefteki ebeveynin kök ailesine karşı yayılan kin ve nefret duygularının varlığı ve çocuğun yabancılaştıran ebeveyne karşı koşulsuz desteği) durumunda EYS'ın düşünülmesi gerektiğini ifade etmiştir (Gardner 1985, Gardner 1998, Gardner 2002). Bu kapsam dahilinde çocukta gözlenen davranışların sıklığını ve şiddetini dikkate alarak EYS'yi hafif, orta ve şiddetli olmak üzere üç farklı yabancılaşma düzeyinde kavramsallaştırmıştır (Gardner 2002) (Bkz. Tablo 1).

\section{Tablo 1. EYS'nin evreleri}

\begin{tabular}{|c|c|}
\hline Hafif düzeyde EYS & $\begin{array}{l}\text { Çocuk, hafif düzeyde yabancılaşma sergilemektedir. Bu düzeyde, yabancılaştıran ebeveyn, sözel veya sözel } \\
\text { olmayan yollarla kendisinin daha iyi bir ebeveyn olduğunu çocuğa empoze etmeye çalışmaktadır. Yabancılaştıran } \\
\text { ebeveyn, hedefteki ebeveyne yönelik olumsuz düşünce ve yaşantılarını ifade etme eğilimindedir. Klinik } \\
\text { belirtilerin yeni yeni ortaya çıktığı bu aşamada çocuk, hedefteki ebeveyniyle iletişim kurmaya devam etmektedir. }\end{array}$ \\
\hline Orta düzeyde EYS & $\begin{array}{l}\text { Çocuk, orta düzeyde yabancılaşma sergilemektedir. Çocukta, yabancılaştığı ebeveynine yönelik öfke, nefret gibi } \\
\text { olumsuz duyguların geliştiği görülmektedir. Hedefteki ebeveyninin kötü olduğunu düşs̈unen çocuk, ona karşı } \\
\text { yıkıı davranışlar sergileme eğilimindedir. Bu süreçte hedefteki ebeveyn, çocuğu ile iletişim kurmakta güçlük } \\
\text { çekmektedir. }\end{array}$ \\
\hline Şiddetli düzeyde EYS & $\begin{array}{l}\text { Çocuk, yoğun düzeyde yabancılaşma sergilemektedir. Hedefteki ebeveynini kendisine düşman olarak gören } \\
\text { çocuk, yabancılaştıran ebeveynin iftira kampanyasının ortağı olabilmektedir. Bu süreçte hedefteki ebeveyn, } \\
\text { çocuğu ile iletişim kuramamaktadır. }\end{array}$ \\
\hline
\end{tabular}

Gardner (1992), klinik gözlemlerinden hareketle boşanma sonrası süreçte velayetin sıklıkla anneye verildiğini ve çocukların babaya karşı EYS geliştirebildiğini belirtmiş olsa da, ilerleyen yıllarda her iki ebeveynin de eşit oranda yabancılaştırma girişiminde bulunduğunu bildirmiştir (Gardner 2002). Bazı durumlarda, yabancılaştıran ebeveynlerin velayet davalarını kendi lehine çevirebilmek için çocuğa yönelik kötü muamele iddialarını gündeme getirdiğini ancak bu iddiaların çoğunlukla gerçeği yansıtmadığını belirterek; bu durumu, yabancılaştıran ebeveynin hedefteki ebeveyni cezalandırmak için kullandığı bir yöntem olarak değerlendirmiştir (Gardner 1992). Bu görüşe paralel olarak Kanada'da bildirilen Çocuk İstismarı ve İhmali Araştırması Raporu (CIS-98) sonuçları incelendiğinde, çocuğa kötü muamele iddialarında kasıtlı olarak \%4 oranında yanlış bildirim yapıldığı, boşanma, velayet davalarında bu oranın \%12 olarak bildirildiği görülmektedir (Trocmé ve Bala 2005). Bu bulgunun aksine alanyazında EYS'nin tanımlanmasıyla birlikte, bazı istismar olgularında ebeveynlerin bilinçli bir manipülasyon gerçekleştirerek yaşanılan sürecin EYS 
olduğunu iddia edebildiği de belirtilmektedir (Torun 2011). Özellikle boşanma ve velayet davalarında çocuğa yönelik kötü muamele iddialarındaki yanlış bildirimler ve EYS'ye yönelik yapılabilecek bilinçli manipülasyon durumları dikkate alındığında, var olan iddiaların titizlikle araştırılarak değerlendirilmesi gerekmektedir (Torun 2017). Bu noktada Gardner (2002), ebeveyni tarafindan ihmal, fiziksel/cinsel istismar, terk edilme gibi travmatik yaşam olaylarını deneyimleyen çocukların da makul gerekçelerle ebeveyne yabancılaşma geliştirebileceğini belirterek, bu gibi durumlarda EYS tanısının geçerli olmayacağını vurgulamıştır. Bu kapsam dahilinde EYS'nin temel unsurları Tablo 2'de sunulmuştur.

\section{Tablo 2. EYS temel unsurlar (Goldin ve Salani 2020)}

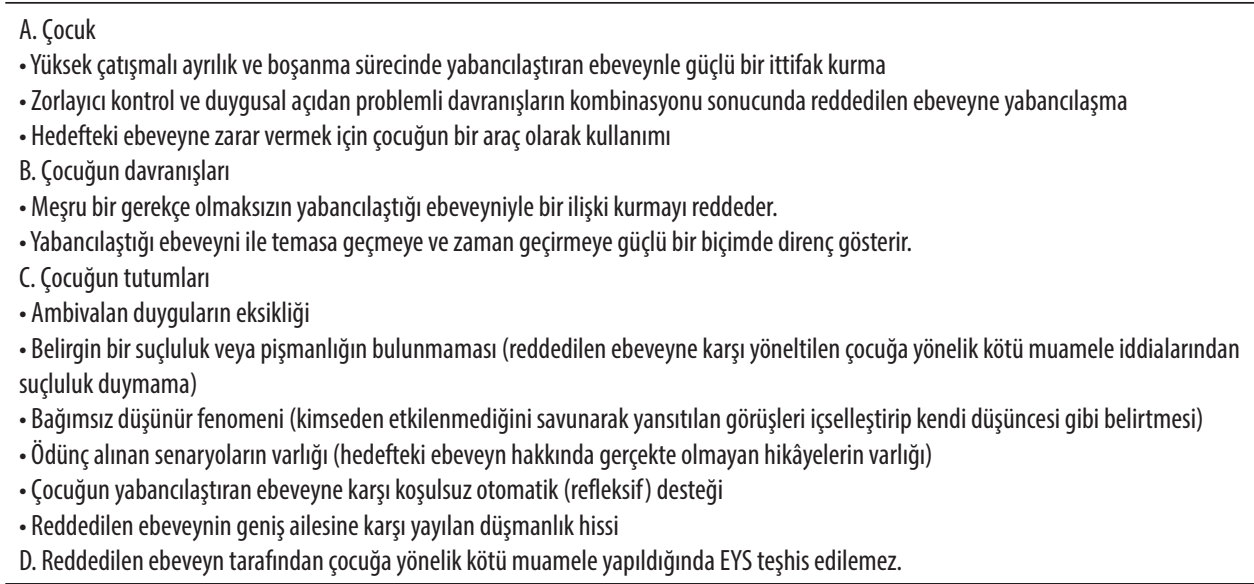

Kelly ve Johnston (2001), EYS'nin hukuki davalarda kötü amaçlarla kullanılması, ebeveyn yabancılaşmasının altında yatan etmenlerin tek bir faktöre bağlı kalınarak açıklanması, teşhis edilebilir "sendrom" olarak tanımlanabilmesi için sınırlı düzeyde ampirik kanıt olması gibi durumlara dikkat çekerek kavramın "yabancılaşan çocuk" çerçevesinde yeniden formüle edilmesinin kritik öneme sahip olduğu belirtmiştir. Bu kapsamda, Kelly ve Johnston (2001), boşanma veya ayrılık sonrasında çocukların ebeveynleriyle olan ilişki örüntülerini; her iki ebeveyniyle de olumlu ilişkiler kurabilen çocuklardan ebeveynlerinden birine yabancılaşan çocuklara doğru devam eden bir süreç içerisinde kavramsallaştırmıştır. Bu sürecin bir ucunda, ayrılık veya boşanma sonrasında her iki ebeveynine değer veren, önemseyen ve vakit geçirmek isteyen çocuklar yer alırken; sürecin diğer ucunda, ayrılık veya boşanma sonrasında bir ebeveynine yönelik gerçekçi bir neden olmaksızın öfke, nefret, korku gibi olumsuz duygular ifade eden ve ebeveyniyle görüşmeye direnç gösteren çocuklar yer almaktadır. Bu noktada, başlangıçta her iki ebeveyniyle de eşit ve sürekli ilişki kurmaya devam eden bir çocuğun; süreç içerisinde bir ebeveynini tercih ederek diğer ebeveyniyle ilişki kurmayı makul bir gerekçe olmaksızın reddetmesi durumunu "yabancılaşan çocuk" kavramı çerçevesinde değerlendiren Kelly ve Johnston (2001), çocuğun ebeveynlerinden birini reddetmesi sürecinde sadece tek başına yabancılaştıran ebeveynin etkisinin yeterli olmadığını, bazı çocukların bu etkiyi kırabilecek güce sahip olabildiğini belirtmiştir. 
Warshak (2003) ise, EYS'nin tanımlanabilmesi için sürekli ve 1srarcı bir şekilde ebeveyn reddi, bu reddin mantıklı bir nedenden kaynaklanmaması ve tercih edilen ebeveynin kısmen de olsa etkisinin bulunması gerektiğini ifade etmiştir. Bu noktada, EYS'nin temel yapısı ve yabancılaşmaya bağlı çocukta gözlenen davranışlar konusunda bir fikir birliği olduğu belirtilebilir (Johnston 2003, Rueda 2004). Ancak, geçmişten günümüze EYS'nin teşhis edilebilir bir sendrom olarak tanınması konusu üzerine farklı görüşlerin ortaya çıktığı görülmektedir (Pepiton ve ark. 2012, Lowenstein 2013, Clemente ve Padilla-Racero 2016). EYS'nin geçerli ve güvenilir bir yapıda olduğu görüşünü savunan bir grup araştırmacı, EYS'nin uluslararası bir düzeyde bozukluk olarak "Rubsal Bozuklukların Tanısal ve Sayımsal El Kitabı (DSM)" ve Dünya Sağlık Örgütü tarafından hazırlanan "Hastalıkların ve Sağlıkla İlgili Sorunların Uluslararası Istatistiksel Sınıflaması (ICD)” içerisinde yer almasının önemine yönelik görüş bildirmiştir. Terminolojik ve etiyolojik açıdan var olan tartışmalara rağmen, evrensel olarak psikoloji ve hukuk alanında çalışan uzmanlar tarafından EYS'nin yaygın olarak gözlendiği, tanımlandığını ve birçok mahkeme tarafından kabul edildiğini vurgulayan araştırmacılar, tanısal kriterlerin belirlenmesi yoluyla, sistematik açıdan değerlendirme, müdahale ve izlem yapılabileceğini belirtmiştir (Bernet ve ark. 2010). Bu görüşlerin aksine bazı araştırmacılar, EYS ile ilgili yapılan araştırmaların yetersizliğine dikkat çekerek (Walker ve ark. 2004, Meier 2009, Walker ve Shapiro 2010, Pepiton ve ark. 2012, Milchman ve ark. 2020) ebeveyn yabancılaşmasının tanıdan çok dinamiklerle ilgili olduğunu iddia etmiştir (Garber 2020). Clarkson ve Clarkson (2008) ise, DSM'de yer alan bozuklukların tanılama sürecinde bireyde gözlenen davranışların dikkate alındığını, ancak EYS’yi birden çok kişinin davranışlarının tanımlandığı kişilerarası bir süreç olduğu gerekçesiyle ayrı bir tanı olarak ele almak yerine, DSM'de yer alan ilişki sorunları bağlamında değerlendirmenin uygun olacağını belirtmiştir. Sonuç itibariyle, EYS ile ilgili araştırmaların yetersiz olması, görülme hızı, zamana bağlı değişim, cinsiyet farklılıkları gibi argümanların tam olarak kanıta dayalı bir biçimde ortaya konulmaması gibi gerekçeler nedeniyle DSM-5 ve ICD-11 içerisine dahil edilmemiştir (Torun 2017).

Bu noktada çağdaş EYS savunucuları, ebeveyne yabancılaşma sonuçlarının DSM- 5'te yer alan "ana-baba ilişkisindeki sıkıntılardan etkilenen çocuk", "ana-baba-çocuk ilişkisi sorunu" ve "çocuğa yönelik psikolojik istismar" gibi terminolojiler yoluyla tanımlanabileceğini belirtmiştir ve terminolojik olarak EYS yerine "ebeveyn yabancılaşması" terimini kullanmayı tercih etmişlerdir (Bernet 2015, Bernet ve ark. 2016, Bernet ve ark. 2018). Bu doğrultuda, Bernet ve ark. (2018) ebeveyn yabancılaşması kavramını, "çoğunlukla, yüksek çatışmalı ayrılıklarda veya boşanma davaları sırasında çocuğun bir ebeveyniyle (tercih edilen veya yabancılaştıran ebeveyn) güçlü bir şekilde ittifak kurduğu ve herhangi bir meşru gerekçe olmaksızın diğer ebeveyniyle (reddedilen veya hedeflenen ebeveyn) ilişki kurmayı reddettiği bilişsel bir durum” olarak tanımlamıştır. Bu süreçlere paralel olarak alanyazında, ebeveyn yabancılaşmasını tanımlamak ve değerlendirmek üzere çeşitli ölçüm araçlarının geliştirildiği (Mone ve Biringen 2012, Sîrbu ve ark. 2021), ebeveyn yabancılaşmasının (bir ebeveynin meşru bir gerekçe olmaksızın reddedilmesi) diğer temas reddi nedenlerinden ayrılması sürecinde Ebeveyn Kabul-Red Ölçeğinin kullanımının yararlığının niceliksel 
araştırmalar yoluyla değerlendirildiği (Bernet ve ark. 2018, Bernet ve ark. 2020, Bernet ve ark. 2020), ebeveyn yabancılaşmasının çocuklar üzerindeki kısa ve uzun süreli olumsuz etkilerine yönelik retrospektif ve niteliksel araştırmalar yapıldığ1 (Baker 2005, Baker 2006, Baker ve Ben-Ami 2011, Baker ve Brassard 2013, Baker ve Verrocchio 2013, Verrocchio ve ark. 2019), yabancılaştıran ebeveynlerin yabancılaştırıcı davranışlarının belirlenmeye çalış1ldı̆̆1 (Baker ve Darnall 2006, Baker ve Fine 2008), yabancılaşmanın aile sistemi üzerindeki yıkıcı etkilerine vurgu yapıldı ğ 1 (Harman ve ark. 2019), reddedilen/hedeflenen ebeveynlerin perspektifi ve yabancılaşma sürecine psikolojik uyumu (Balmer ve ark. 2018, Tavares ve ark. 2020) gibi konular üzerinde niceliksel ve niteliksel araştırmaların ağırlıklı olarak yapıldığı, sahada çalışan uzmanların karşılaştığı EYS ile ilgili öznel deneyimlerine odaklanıldığ1 (Bow ve ark. 2009, Viljoen ve van Rensburg 2014, Braver ve Lamb 2018) ve sistematik derleme çalışmalarının (Templer ve ark. 2016, Lee-Maturana ve ark. 2018, Marchetti ve Verrocchio 2017, Marques ve ark. 2020) yapıldığ görülmektedir. Literatürde her ne kadar ebeveyn yabancılaşmasıyla ilgili tartışmalara devam edilse de günümüzde kavramın yaygın olarak görülüp tanımlandığı ve bugüne kadar konu üzerine 1.000'den fazla kitap, kitap bölümü ve 500'den fazla makalenin yayınlandığı belirtilse de (Bernet ark. 2010, Goldin ve Salani 2020, Parental Alienation Database 2020) konunun bilinmeyen yönlerinin yeni yapılacak çalışmalarla aydınlatılması gerektiği belirtilmektedir (Torun 2011, Torun 2017).

Günümüzde, ayrılma ve boşanma sonrasında ebeveyn yabancılaşmasının daha geniş bir perspektif çerçevesinde açıklanmaya çalışıldığı görülmektedir (Kelly 2007, Friedlander ve Walters 2010, Johnston ve Sullivan 2020). Ebeveyn yabancılaşmasında her ne kadar yabancılaştırıcı ebeveyninin etkisinin önemli olduğu kabul edilse de bu süreçte ebeveynlerin kişilik özellikleri, ebeveynlik stilleri, reddedilen ebeveynin yabancılaştırma girişimlerine verdiği tepkiler gibi unsurların da etkili olabileceği belirtilmektedir (Johnston ve ark. 2005, Gordon ve ark. 2008, Drozd ve ark. 2016, Johnston ve Sullivan 2020, Warshak 2020). Bu noktada, ebeveyne yabancılaşma sürecinde etkili olabilecek risk faktörleri arasındaki dinamik etkileşimin ekolojik sistem yaklaşımıyla teorik bir çerçevede açıklanmasının faydalı olacağı düşünülmektedir.

\section{Ekolojik sistemler kuramı}

Ekolojik Sistemler Kuramı bireyin gelişimini; kişinin çevresini oluşturan ilişkiler sistemi bağlamında incelemektedir. Bronfenbrenner, bireyin çevresini oluşturan katmanları tanımlayarak, her bir katmanın erken dönemden itibaren çocuğun gelişimi üzerindeki etkisini açıklamıştır (Bronfenbrenner 1979). Bireyin gelişimi üzerinde doğuştan getirilen biyolojik özelliklerin de etkisi olduğu düşünüldüğünde, teori yakın zaman içinde "biyoekolojik sistem teorisi” olarak yeniden adlandırılmıştır. Çocuğun gelişimi, olgunlaşma ve çevrenin etkileşimi doğrultusunda şekillenmektedir. Bu doğrultuda, çocuğun gelişimi değerlendirilirken, sadece çocuk ve çocuğun yakın çevresi değil, aynı zamanda çocuğun genişleyen çevresiyle olan etkileşiminin de incelenmesi gerekmektedir (Härkönen 2007). Ekolojik sistem yaklaşımına göre; birbiri içine yerleşmiş sistemler ve bu sistemlerin birbiriyle olan etkileşimi, çocuğun 
gelişimsel sürecini anlamlandırmaya katkı sağlamaktadır. Bu sistemler, mikrosistem, mezosistem, ekzosistem, makrosistem ve kronosistem olarak adlandırılmaktadır (Eliasa 2012).

Ebeveyn yabancılaşması üzerine yapılan çalışmalarda, yabancılaşmanın, yalnızca çocuğun bireysel özelliklerinden kaynaklanmadığ 1 aksine yabancılaştıran ebeveynler, hedefteki ebeveynler, akrabalar, adli süreçte yaşanan deneyimler gibi farklı süreçlerin birbiri ile olan dinamik etkileşimleri sonucu yabancılaşmanın meydana geldiği ve bu sürecin çocuk açısından duygusal bir istismar türü olduğu belirtilmektedir (Torun 2017). Bu kapsamda çocuğun çevresinde var olan sistemlerin, yabancılaşma sürecindeki etkisini irdelemek; erken dönemde müdahale ve izlem noktasında gerekli önlemleri almak açısından önemli görünmektedir.

\section{Sistemler boyutunda ebeveyn yabancılaşması (EYS)}

\section{Mikrosistem}

Mikrosistem, bireyin içinde yaşadığı kişinin ailesi, akranları, okulu ve mahallesi gibi bağlamları içeren ortamdır. Bu sistemde çocuk; ebeveyni, akranları, öğretmenleri gibi çeşitli sosyal aktörlerle doğrudan etkileşim kurabilmektedir (Santrock 2014). Mikrosistem, okul ve rekreasyon grupları gibi geniş ortamları temsil etse de ebeveyn yabancılaşması açısından bu bölümdeki odak aile olacaktır.

Mikro düzeyde yabancılaşma sürecinin, temel olarak yabancılaştıran ebeveynle ilişkili olduğu düşünülmektedir. Torun (2017) yabancılaştıran ebeveynlerin, boşanma sonrasında çocukla aynı ortamı paylaşan ve çocukla daha fazla vakit geçiren ebeveynler olduğunu belirtmektedir. Boşanma süresinde, yabancılaştıran ebeveyn, kendi kişisel çıkarları, geçmişi veya psikolojik problemlerinden dolayı doğrudan ve dolaylı faaliyetler göstererek, çocuğu eşler arası çatışmanın odağı haline getirmekte, çocuğun hedefteki ebeveyni reddetmesi amacıyla çeşitli girişimlerde bulunabilmektedir (Drozd ve Olesen 2004). Baker ve Darnall (2006) yabancılaştıran ebeveynlerin duygusal açıdan gerici ve manipüle edici davranışlar sergileyerek çocuklarının hedefteki ebeveyniyle olan iletişimini sınırlandırdı̆̆ını ifade etmektedir. Alanyazında yabancılaştıran ebeveynlerin, çocuklarıyla olan ilişkisinde hedefteki ebeveyne karşı on yedi farklı yabancılaştırma stratejisi kullandığı belirtilmektedir (Baker ve Fine 2008). Bu stratejiler; kötü söz söyleme, iletişimi engelleme ve ilişki kurmayı sınırlama, sembolik iletişimin kurulmasına engel olma, sevginin geri çekilmesi, çocuğu seçim yapmaya zorlama, çocuğa hedefteki ebeveynin çocuğu sevmediğinin söylenmesi, çocukta şüphe yaratma, çocuğun hedefteki ebeveyni reddetmesi için baskıda bulunma, hedefteki ebeveynin tehlikeli olduğu izlenimi oluşturma, çocuktan hedefteki ebeveyne karşı ajanlık yapmasını teklif etme, çocukta kuşku yaratma, çocuğa hedefteki ebeveynle sırlarının saklanmasını isteme, hedefteki ebeveyne isimle hitap edilmesini sağlama, yabancılaştıran ebeveynin olası yeni eşini çocuğa anne/baba olarak tanıtma, çocuğun adını soyadını değiştirme, hedefteki ebeveynden çocuğun tıbbi, akademik ve diğer önemli bilgilerini saklama, çocuğu bağımlı hale getirme şeklindedir. 
Çocuğun gelişim özellikleri ve gelişimsel gereksinimleri, farklı mikrosistemler ile olan ilişkilerde değişimlerin meydana gelmesine neden olmaktadır. Örneğin; bebeklik döneminde ebeveyn-çocuk etkileşimiyle ergenlik dönemindeki ebeveyn-çocuk etkileşimi birçok açıdan farklılık gösterebilmektedir (Doğan 2010). Bu perspektif doğrultusunda yabancılaştıran ebeveyn-çocuk etkileşiminde, ebeveynin kullandığg1 yabancılaştırma davranışlarının çocuğun içinde bulunduğu gelişim dönemine ve gelişimsel gereksinimlerine bağlı olarak değişiklik gösterebileceği belirtilebilir. Benzer şekilde çocuğun yabancılaştırma girişimlerine gösterdiği tepkiler ve bu girişimlerin çocuk üzerindeki etkilerinin yaş ve gelişim özelliklerine bağlı olarak farklılık göstermesi muhtemeldir. Bu görüşe paralel olarak; Lowenstein (1999), çocukların yaş ve gelişim özelliklerine bağlı olarak; yabancılaşma durumu sonrası gösterdikleri tepkiler arasında farklılıkların söz konusu olduğunu ve ebeveyn yabancılaşmasının yıkıcı etkilerinin kısa ve uzun vadede ortaya farklı şekillerde çıkabildiğini belirtmektedir. Mevcut yayınlar incelendiğinde (Lowenstein 1999, Baker 2005, Baker 2006, Baker ve Ben-Ami 2011, Baker ve Brassard 2013, Baker ve Verrocchio 2013, Sher 2015, von Boch-Galhau 2018, Verrocchio ve ark. 2019) bu etkiler; öfke, üzüntü, hayal kırıklı̆̆1, korku, dürtü kontrol yetersizliği, düşük benlik saygısı ve özgüven eksikliği, bağlanma ve ayrılık kaygısı, çeşitli durumlara ilişkin fobiler geliştirme, depresyon ve intihar düşüncesi, uyku bozuklukları, enürezis ve enkoprezis, yemek yeme problemleri, anksiyete, panik atak, madde kötüye kullanımı, cinsel kimlik problemleri, zayıf akran ilişkileri ve eğitim problemleri olarak belirtilmektedir. Görüldüğü üzere, çocuk açısından, ebeveyn yabancılaşmasının yıkıcı etkileri davranışsal, bilişsel ve psikososyal düzeyde farklı şekillerde ortaya çıkabilmektedir. Bu kapsamda, yabancılaştıran ebeveyn ve yabancılaştırma girişimlerinin mikrosistem düzeyinde önemli bir risk faktörü olduğu belirtilebilir.

Mikro düzeyde hedefteki ebeveyn-çocuk etkileşiminin de ebeveyn yabancilaşması bağlamında önemli bir etkiye sahip olduğu düşünülmektedir. Boşanma sonrasında hedefteki ebeveynin yaşadığı üzüntü, sevgi dolu bir ebeveyn-çocuk ilişkisinin kaybıyla daha da artmaktadır. Farkas (2011), bu süreçte hedefteki ebeveynlerin çocuklarıyla telefon, mektup, mesaj, elektronik posta aracılığıyla iletişim kurmaya çalışması, geçmişteki ilişkilerinde yaşanan eğlenceli, keyifli ve unutulmaz anıları çocuklarına hatırlatmasının pozitif yönde etkili olabileceğini belirtmiştir. Ağır düzeyde yabancılaşmanın olduğu durumlarda bile ebeveynin çocuğu ile iletişim kurmaya çalışması, özel günleri hatırlaması, hediye göndermesi çocuğun gerçekliğe olan yönelimini artırmaktadır (Farkas 2011). Yabancılaştırma stratejilerine maruz kalan bir çocuğun, hedefteki ebeveynin bu ithamların aksi yönündeki davranışlarıyla karşılaşması durumu, bilişsel açıdan çelişki yaşamasına ve psikolojik açıdan sıkışmış hissetmesine neden olabilir. Bu noktada hedefteki ebeveynin, çocuğun bireysel özelliklerini dikkate alarak var olan duygu, düşünce ve davranışlarını anlamaya çalışması, çocuğun yaşayabileceği bu çelişki durumunun onun için ne kadar zor olabileceğini göz önünde bulundurarak hareket etmesi oldukça önemlidir. Bu bilgilerden yola çıkılarak, hedefteki ebeveynin çocuğu ile iletişim kurmak için çaba sarf etmesinin; çocuğun ebeveynine yönelik gerçekçi olmayan algılarının değişmesine katkı sağlayabileceği belirtilebilir. Bu kapsamda, ebeveyn yabancılaşması bağlamında hedefteki ebeveynin çocuğu 
ile iletişim kurma girişimlerinin mikrosistem düzeyinde koruyucu ve önleyici bir öneme sahip olduğu düşünülmektedir.

Ebeveyn yabancılaşması sürecinde çocuğun tutumlarının yalnızca reddedilen ebeveyne yönelik olmadığı, bazı koşullarda reddedilen ebeveynin geniş ailesine karşı da düşmanlık hissinin yayılabileceği belirtilmektedir (Bkz. Tablo 2). Bu doğrultuda mikro düzeyde, geniş aile üyelerinin de çocuk üzerinde önemli bir etkiye sahip olduğu düşünülmektedir. Torun (2017), boşanma sürecinde geniş aile üyelerinin de ebeveynler arasındaki çatışmaya farklı biçimlerde dahil olabildiğini ifade etmektedir. Torun'a göre (2017) ebeveyne yabancılaşma sürecinde genellikle yabancılaştıran ebeveynin geniş ailesi de rol oynamaktadır ve hedefteki ebeveyne yönelik yapılan beyin yıkama kampanyasına sorgusuz bir biçimde destek vermektedir. Hedefteki ebeveynin geniş ailesi ise, kendi çocuklarına karşı atılan iftiraların ve iddiaların doğru olup olmadığına şüphe ile yaklaşırken, torunlarının belirttiği ifadelerin doğruluğunu sorgulamaya başlamaktadır. Genel olarak karşı tarafın kararlılığı karşısında, sürecin çözümlenmesinin güç olduğunu fark ederek, çocuklarını bu savaştan vazgeçirmeye çalışmaktadır. Bazı durumlarda hedefteki ebeveynin geniş ailesi, torunlarını kaybetmekten korktuğu için süreç içerisinde tarafsız kalmayı tercih etmesine rağmen torunları tarafindan iftira sürecinin bir parçası olabilmektedir. Alanyazında, bu süreçten en çok etkilenen kişilerin çocuklar olduğu belirtilmektedir (Cartwright 1993, Beiner ve ark. 2014, Kaganas ve Piper 2020). Cartwright'e göre (1993) çocuk bu süreçte yalnızca ebeveynine yabancılaşmakla kalmayıp aynı zamanda büyükanne, büyükbaba, akraba ve ebeveynin arkadaşları ile görüşmeyi de reddetmektedir. Yabancılaştıran ebeveynin, hedefteki ebeveynin akraba ve arkadaşlarına yönelik kasten ve sistematik olarak gerçekleştirdiği girişimler, çocuğun akrabaları ile geçirebileceği güzel anıların önünde bir set oluşturmaktadır.

Tüm bu bilgiler doğrultusunda, mikro sistem düzeyinde yabanc1laştıran ebeveynin ve geniş ailenin çocuk ile kurduğu ilişki örüntülerinin çeşitli açılardan risk faktörü taşıdığı ancak hedefteki ebeveynin iletişim kurmak için çaba göstermesi durumunun yabancılaşmayı önleme açısından koruyucu öneme sahip olduğu belirtilebilir.

\section{Mezosistem}

Mezosistem, gelişmekte olan kişinin aktif olarak katıldığı, iki veya daha fazla bağlam arasındaki ilişkileri ve bağlantıları içermektedir. Mezosistem, kişinin yaşamındaki farklı mikrosistemler arasında bir ilişki ağı oluşturmaktadır (Bronfenbrenner 1979). Bu bağlamda; aile ve okul, aile ve arkadaşlar, aile ve öğretmenler arasındaki etkileşimlerin çocuk açısından en temel mezosistem yapılarını oluşturduğunu söylemek mümkündür. Alanyazında, ebeveynler arası çatışmaların ortasında kalan ve bir ebeveynine karşı yabancılaşma geliştiren çocukların, okulla ilgili sorunlar geliştirmesinin yaygın olduğu belirtilmektedir (Clawar ve Rivlin 1991). $\mathrm{Bu}$ doğrultuda, boşanma sürecinde hedefteki ebeveyne karşı yabancılaşma stratejilerine maruz kalan çocukların deneyimlerinin, okul ortamında akranlarla ve öğretmenlerle yaşanan etkileşim sürecini etkileyebileceği düşüncesinden yola çıkılarak bu bölümde odak okul yaşamı olacaktır. 
Yabancılaştıran ebeveyn, çocuğun hayatındaki önemli olaylar veya okulla ilgili durumlar hakkında hedefteki ebeveyni bilgilendirmemekle birlikte bazı durumlarda okullardan çocuğun gerçek kimlik bilgilerini gizleyerek hedefteki ebeveynlere bilgi akışını engelleme eğiliminde olabilmektedir (Steinberger 2006). Ayrıca bazı durumlarda, yabancılaştıran ebeveynlerin, kendi gereksinimlerini ön planda tutup çocukların eğitim ihtiyaçlarını ötelemesi sonucu çocuklar düzenli olarak okula devam edememe riski ile karşı karşıya kalabilmektedir. Haines ve ark. (2019), yabancılaştıran ebeveynlerin sadece çocuklarını manipüle etmediğini aynı zamanda okul öğretmenlerini, müdürlerini, okul personelini de manipüle etme girişiminde bulunduğunu belirtmektedir. Yabancılaştıran ebeveynler, hedefteki ebeveynin çocuğu ile olan temasını sınırlandırmak için okul personelinden, çocuk hakkındaki bilgilerin hedefteki ebeveynle paylaşılmamasını talep edebilmektedir (Baker ve Darnall 2006). Bu süreçte yabancılaştıran ebeveyn; hedeflenen ebeveyn hakkında gerçekte olmayan suçlayıcı ithamlarda bulunarak okul personelini ikna edebilmektedir. Yabancılaştıran ebeveynlerin, hedefteki ebeveyni manipüle etmek için başvurduğu çeşitli stratejiler sonrası, okul personeli ile hedefteki ebeveyn arasındaki iletişim ve etkileşim bozulmaktadır. Okul personelinin de hedefteki ebeveyne karşı temkinli tutumunu fark eden çocuk, yabancılaştıran ebeveynin ifadelerinin doğruluğuna olan inancını güçlendirebilmektedir (Haines ve ark. 2019). Bu doğrultuda, yabancılaştıran ebeveyn ve okul arasındaki ilişki örüntüsünün, çocuğun hedefteki ebeveynine yönelik algılarını olumsuz yönde etkileme potansiyeline sahip olduğu söylenebilir.

Mezosistem düzeyinde, yabancılaştıran ebeveynin kullandığ 1 stratejilerin, sadece okul personelini değil aynı zamanda çocuğun akranlarının ebeveynleri üzerinde de etkili olabileceği düşünülmektedir. Örneğin; hedefteki ebeveyne yönelik gerçekçi olmayan senaryolara maruz kalan çocuğun akranlarının ebeveynleri, akranlar arası etkileşimi sınırlandırmaya, kontrol etmeye çalı̧̧abilir. Bu durum, çocuklar arasındaki ilişkinin negatif yönde etkilenmesi, arkadaşlıklarının bozulması gibi sonuçları doğurabilir.

Tüm bu bilgiler doğrultusunda; mezosistem düzeyinde, yabancılaştıran ebeveynin farklı bağlamlarla kurabileceği iletişim ağlarının, çocuk üzerinde çeşitli açılardan risk faktörlerini içinde barındırdığı söylenebilir. Bu bağlamda okul personellerinin bu tür olgulara yönelik farkındalık düzeyinin artırılmasının çocuk ve hedefteki ebeveyn açısından koruyucu bir öneme sahip olduğu sonucuna varılabilir.

\section{Ekzosistem}

Ekzosistem, bireyin aktif rolünün olmadığı sosyal bir ortamla, bireyin yakın bağlamı arasındaki bağlantılardan oluşmaktadır (Santrock 2014). Mezosistemin bir uzantısı olan hem resmi hem de resmi olmayan sosyal yapılardan oluşan bu sistemde (kamu kurumları, profesyonel kuruluşlar vb.), gelişmekte olan kişinin aktif rolü olmasa da, kişi bu yapılarda meydana gelen değişimler ve gelişimlerden etkilenmektedir (Bronfenbrenner 1979). Bala ve ark. (2010), ebeveyne yabancılaşma sürecinin dinamikleri ve ilgili olgular hakkında farkındalık kazanılması için durumun hem yasal hem de psikolojik yönlerinin çok boyutlu bir şekilde ele alınması gerektiğini belirtmektedir. Bu doğrultuda, boşanmanın 
yasal boyutunda yaşanan deneyimlerin, ebeveyne yabancılaşma süreci üzerinde etkili olabileceği düşünülmekte olup bu bölümde odak hakimler, savcılar, avukatlar, ruh sağllğ profesyonelleri gibi boşanmanın adli boyutunda yer alabileceği öngörülen profesyoneller olacaktır.

Eşlerin evlilik sürecinde yaşadığı çatışmalar, boşanma kararıyla birlikte hukuki açıdan avukatlar ve hakimler gibi profesyonellerin aldığ1 kararlar doğrultusunda şekillenmekte olup bu etkileşim ağı, çocuğun yaşantısı üzerinde önemli bir etkiye sahip olabilmektedir. Bir zamanlar ebeveynler arasında karar verilen konular, bu süreçte avukatlar ve hakimler gibi üçüncü taraflarca kararlaştırılmaktadır (Girdner 1985). Alınan kararlar doğrultusunda, her iki ebeveynin de çocuklara olan erişimi değişmekte olup, boşanmanın aile üzerinde etkisi yıkıcı olabilmektedir (Erdim ve Ergün 2016). Adli süreç sonrasında ebeveynler ve çocukların, istedikleri zaman etkileşim kurma özgürlüğü sınırlanmakta ve süreçte yasal olarak uyulması gereken kurallar belirlenmektedir. Boşanma sonrası, çocuğun velayetinin öncelikli olarak bir ebeveyne verilmesi sonucunda çocuk, zamanının büyük bir çoğunluğunu velayete sahip ebeveynle geçirmeye başlamaktadır. Diğer ebeveyn ise çocuğuyla sadece belirli bir zaman diliminde görüşmesine izin verilen bir "ziyaretçi" konumuna gelebilmektedir (Vassiliou ve Cartwright 2001). Ülkemizde yapılan, boşanan çiftlerin mahkeme süreci ve boşanma sonrası yaşam deneyimlerinin incelendiği bir çalışmada, çiftlerin büyük bir çoğunluğunun boşanma sürecini genel olarak duygusal ve psikolojik açıdan sıkıntılı bir dönem olarak değerlendirdiği; boşanma sürecinden olumsuz yönde etkilenen velayete sahip ebeveynlerin öfke/kızgınlık hissiyle çocuklarının, eski eşleriyle kişisel görüşme haklarını engellemeye çalışma eğiliminde olduğu belirtilmektedir (Şen 2015). Türkiye Cumhuriyeti Anayasası 2709 sayılı kanunu Sosyal ve Ekonomik Haklar ve Ödevler bölümünde her çocuğun korunma ve bakımdan yararlanma, yüksek yararına aykırı olmadıkça, ebeveynleri ile kişisel ve doğrudan ilişki kurma ve kurduğu ilişkiyi sürdürme hakkına sahip olduğu belirtilmektedir (Resmi Gazete 1982). İlgili hükme rağmen, boşanma sonrası velayeti alan ebeveynin; diğer ebeveyne karşı engelleyici davranışları, çocukların hedefteki ebeveynine karşı yabancılaşma geliştirmesine ve hedefteki ebeveyniyle iletişime girmeyi reddetmesine neden olabilmektedir. Bu durum, kısa ve uzun dönemde çocuk açısından birçok risk faktörünü de beraberinde getirmektedir. Bu doğrultuda, boşanmanın hukuki boyutunda yer alan profesyonellerin ebeveyn yabancılaşması konusundaki bilgisi ve kavramla olan tanışıklığının davaların seyri açısından önemli bir etkiye sahip olabileceği düşünülmektedir.

Torun (2017) ebeveyn yabancılaşmasının profesyoneller ve mahkemeler tarafından bilinmediği durumlarda, yabancilaştıran ebeveynlerin kolaylıkla programlama yapabildiğini belirtmektedir. Bazı durumlarda hakimler, çiftler arasındaki çatışma durumunu değerlendirmek ve bu duruma müdahale etmek amaciyla psikiyatrist veya klinik psikologlardan görüş istemektedir. Yabancılaştıran ebeveynin hedefteki ebeveyne yönelik iddialarının uzmanlar tarafından ayrıntılı bir şekilde değerlendirilmesi yoluyla hakimler, çocuğun yüksek yararını dikkate alarak karar verebilmektedir (Lowenstein 1998). Bu süreçte ebeveynlerden birinin, diğger ebeveynin çocuğa yönelik davranışları 
konusunda belirtmiş olduğu çeşitli iddiaların doğru olması durumunda, velayetin iddia sahibine verilmesi, çocuk açısından hayati öneme sahip olabilmektedir. Bazen, ebeveynin iddiaları gerçek olmakla birlikte; kanıtlanamaz olabilir. Bu gibi durumlarda velayetin çocuğa kötü muamele sergileyen ebeveyne verilmesi sonucunda çocuk, ihmal ve istismara daha açık hale gelebilmektedir. Aksine iddiaların gerçeği yansıtmaması durumunda alınan velayet kararıyla birlikte çocuk, yabancılaştıran ebeveynin yabancılaştırma stratejilerine maruz kalma riskiyle karşı karşıya kalacaktır. Bu durum, çocuğun zamanla hedefteki ebeveyninden uzaklaşmasına, onunla iletişim kurmayı reddetmesine ve ona karş1 yabancılaşma geliştirmesine neden olabilecektir (Torun 2017).

Yüksek çatışmalı boşanma davaları sırasında hakimler bir ebeveyne karşı yabancılaşma geliştiren çocuklarla karşılaşabilmektedir. Bala ve ark. (2010), mahkemelerde boşanma ve velayet davalarında çocukların yüksek yararı gözetilerek ve maksimum temas ilkesi dikkate alınarak kararlar alınması gerektiğini belirtmektedir. Maksimum temas ilkesi gözetilerek alınan kararlarda mahkemeler, velayeti alan ebeveynin kasıtlı olarak çocuğun diğer ebeveynle olan temasını engelleme veya çocuğu diğer ebeveynden uzaklaştırma ihtimalini dikkate alarak; boşanma sonrası süreçte, çocuğun her iki ebeveyniyle de tutarlı ve yakın bir temas halinde olmasını sağlamayı amaçlamaktadır. Hakimler, hafif düzeyde gözlenen ebeveyn yabancılaşması olgularında, çocuğun diğer ebeveyniyle olan ilişkisini desteklemek amacıyla sık ziyaret ve görüşme gibi adli müdahalelerde bulunarak problem durumu çözümleyebilmektedir. Ancak, orta ve ağır düzey yabancılaşma olgularında hakimlerin, ruh sağlı̆̆ı uzmanlarından görüş isteyerek kapsamlı bir destek ve müdahale planı oluşturulmasına yönelik kararların alınmasını sağlamalarının işlevsel olabileceği belirtilmektedir (Darnall 2011). Bu gibi kararlar yoluyla, çocukların boşanma sonrası süreçte her iki ebeveyniyle de yakın ilişki kurmaya devam edebileceği ifade edilebilir.

Ebeveyn yabancılaşması konusunayönelikülkemizde de akademik alanda çeşitli çalışmaların yapıldığ 1 görülse de (Torun 2011, Şen 2015, Güler 2017, Ziyalar ve Altuntaş 2018, Geniş ve ark. 2019, Ulutürk 2019, Karadağ ve Özdemir 2020) özellikle hukuki boyutta velayet davalar1 sürecini içeren çalışmaların sınırlı düzeyde olduğu göze çarpmaktadır. Erdoğan’ın (2014) ülkemizde yaşanan boşanma ve velayet davalarında kayıtlara geçen raporları incelediği kitabında, uzmanların genel olarak yabancılaştıran ebeveynlerin hedefteki ebeveyne yönelik ithamları üzerine odaklandığı ve yabancılaştıran ebeveynler tarafından çocuklara uygulanan duygusal istismarın göz ardı edebildiği belirtilmektedir. Ayrıca örnek raporlarda, ebeveyn yabancılaşması açısından detaylı bir değerlendirme yapılmaması nedeniyle çocuğun, hedefteki ebeveyni ile tüm velayeti koparma aşamasına geldiği; çocukların depresyon, travma sonrası stres bozukluğu gibi tanılarla psikososyal destek birimlerine yönlendirilmesi üzerine kararlar alındığı görülmektedir. Çocuk yetiştirme konusunda çocuğa bakım sağlama, rehber olma ve sevgi gösterme gibi hususlarda her iki ebeveynin de önemli rollere sahip olduğu düşünüldüğünde, boşanma ve velayet davalarında nitelikli kararların alınabilmesi için sahada çalışan profesyonellere büyük görev ve sorumluluklar düşmektedir.

Tüm bu bilgiler doğrultusunda, ekzosistem düzeyinde, yabancılaştıran ebeveynin hedefteki ebeveyne yönelik ithamları ve hedefteki ebeveynin savunmaları arasında nihai 
karar vericilerin, hukuk alanında çalışan profesyoneller olduğu belirtilebilir. Hakimlerin, elde edilen bilgiler doğrultusunda yasaları yorumlayarak vermiş olduğu kararların, çocukların yaşantıları üzerinde önemli bir etkiye sahip olabileceği düşünülmektedir. $\mathrm{Bu}$ kapsamda da boşanma sürecinde ilgili profesyonellerin ebeveyn yabancılaşması hakkında bilgili olması ve verilecek kararlarda bu durumun da uygun şekilde değerlendirilmesinin ve ilgili diğer uzmanlarla işbirliği yapılmasının büyük bir öneme sahip olduğu belirtilebilir.

\section{Makrosistem}

Geniş toplumsal bağlamın tamamını içeren makrosistem temel olarak kültürle ilgilidir. Kültür ve alt kültürlerle birlikte var olan makrosistem; mikrosistemi, mezosistemi ve ekzosistemi önemli bir biçimde etkilemektedir (Bronfenbrenner 1979). Makrosistemler, toplumun üyelerinin çoğunluğunun içinde bulunduğu, kişinin içinde büyüdüğü dil, din, kanunlar, gelenekler, değerler, tutumlar, kitle iletişim araçları gibi sosyo kültürel, ekonomik, politik, hukuki ve fiziksel yapıyı ve grup yaşantısını içeren kompleks bir boyuttur (Akt. Yıldırım ve Işıkhan 2018). Toplumun inanç ve değer sistemleri ile tarihsel, politik ve hukuki yapısı makrosistemi belirlemektedir. Makrosistem, sosyal yapının diğer tüm yönleri üzerinde önemli bir etkiye sahiptir. Kişi, makrosistemdeki değişimlerden dolaylı olarak etkilenmektedir (Doğan 2010). Makrosistemin dolaylı etkileri, büyük kurumların mezosistem, topluluk ekosistemi ve hatta daha küçük mikrosistemler arasındaki ilişkiler düzeyinde gözlenmektedir (Betancourt ve Khan 2008). Bu doğrultuda, ebeveyn yabancılaşmasında makrosistemin etkilerinin göz ardı edilmemesi gerektiği düşünülmekte olup bu bölümde odak ebeveyn yabancılaşmasının oluşumuna ve çözümüne ilişkin doğru bilinen yanlış inanışlar olacaktır.

Ebeveyn yabancılaşması yaygın olarak görülüp tanımlanmasına rağmen, kavramın geçerliğine ve hukuk alanında kullanımına yönelik tartışmaların olduğu görülmektedir (Johnston ve Sullivan 2020). Toplumsal düzeyde ebeveyn yabancılaşmasına bakış açısını belirleme noktasında var olan tartı̧̧maların ve fikir ayrılıklarının önemli olduğu düşünülmektedir.

Torun'a (2017) göre ebeveyn yabancılaşmasına yaklaşım ve çözümü sürecinde, daha çok yaşanılan deneyimlerden hareketle yorumlamalar yapılmakta, süreç içerisinde deneyimlenen yaklaşımlar kulaktan kulağa aktarılarak doğruymuş gibi hareket edilmeye başlanmaktadır. Geçerliği ve güvenirliği bilimsel açıdan desteklenmeyen, yalnızca kişisel deneyimlerden hareketle yapılan yorumlamalar ve gözlemler toplum tarafindan doğru bilenen ancak yanlış olan inanışların oluşumuna sebep olmaktadır. Warshak (2015), toplum tarafindan ebeveyn yabancılaşmasının oluşumuna ve çözümüne geliştirilen yanlış inanışları on madde üzerinden değerlendirmiştir. Ebeveyn yabancılaşmasının oluşumu ve çözümü ile ilgili mitler Tablo 3’te yer almaktadir. 
Tablo 3. Ebeveyn yabancılaşmasının oluşumu ve çözümü ile ilgili mitler

\begin{tabular}{|c|c|}
\hline \multirow{5}{*}{ 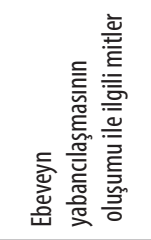 } & 1. Çocuklar zamanın büyük bir çoğunluğunu birlikte geçirdiği ebeveynini sebepsiz bir şekilde asla reddetmez. \\
\hline & 2. Çocuklar, annelerini sebepsiz yere asla reddetmez. \\
\hline & 3. Her ebeveyn, çocuğun yabancılaşmasına eşit düzeyde katkıda bulunmaktadır. \\
\hline & 4. Yabancılaşma, ebeveynlerin ayrılığına çocuklar tarafından verilen kısa süreli, geçici bir tepkidir. \\
\hline & 5. Bir ebeveynin kısa süreli reddedilmesi, çocuğun boşanma sürecinde kullandığı sağlıklı bir baş etme mekanizmasıdır. \\
\hline \multirow{5}{*}{ 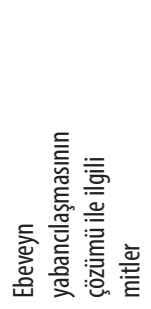 } & 6. Yabancılaştıran ebeveynle birlikte yaşayan küçük çocukların müdahaleye ihtiyacı yoktur. \\
\hline & 7. Ebeveyne yabancılaşma geliştiren ergenin belirttiği tercihe göre velayet kararı verilmelidir. \\
\hline & $\begin{array}{l}\text { 8. Bir ebeveynini mantıksız bir biçimde reddeden ancak diğer alanlarda problem yaşamayan çocukların terapötik } \\
\text { açıdan desteğe ihtiyacı yoktur. }\end{array}$ \\
\hline & $\begin{array}{l}\text { 9. Ağır düzeyde ebeveyne yabancılaşma geliştiren çocuklara, yabancılaştıran ebeveynleriyle birlikte yaşarken } \\
\text { geleneksel terapi yöntemleri kullanılarak müdahale edilebilir. }\end{array}$ \\
\hline & 10. Çocukların yabancılaştıran ebeveynden ayrılması, travmatik bir durumdur. \\
\hline
\end{tabular}

Ebeveyn yabancılaşmasının oluşumu ve çözümlerine yönelik olan bu gibi mitlerin hukuk, politika, kanunlar gibi makrosistemi oluşturan yapıları etkileyebileceği düşünülmektedir. Warshak (2015), ebeveyn yabancılaşmasının oluşumuna ve çözüm yollarına yönelik geliştirilen yanlış inanışlar sonucunda, avukatların, hakimlerin, terapistlerin, aile bireylerinin ve sosyal çevrenin yanlış yönlendirmeler yapabildiğini belirtmektedir. Yanlış yönlendirmeleri dikkate alan sahada çalışan profesyoneller de çocuğun yabancılaşma durumuna yönelik olarak alternatif açıklamalar geliştirmeye gereksinim duymamaktadır. Bu durum, velayet davalarında çocukların gereksinimlerini karşılamayan fikirlerin ve kararların alınmasına neden olmaktadır (Warshak 2015).

Tüm bu bilgiler doğrultusunda, makrosistem düzeyinde, ebeveyn yabancılaşmasının oluşumuna ve çözümüne ilişkin doğru bilinen yanlışların, toplumsal yapı üzerine yansımalarının olumsuz yönde olacağı belirtilebilir. Bu bağlamda, ebeveyn yabancılaşmasının oluşumu ve çözümlerine yönelik makro düzeyde toplumu bilgilendiren çalışmaların yapılmasının gerekli olduğu düşünülmektedir.

\section{Kronosistem}

Kronosistem, bireyin içinde yaşadığ1 çevrede zaman içinde meydana gelen değişimlerin çocuğun gelişimi üzerinde ne ölçüde etkili olduğuna odaklanmaktadır. Bronfenbrenner (1986), zaman içerisinde meydana gelen bu değişimleri; normatif (okula başlama, ergenlik, evlilik, emeklilik) ve normatif olmayan (boşanma, ailede kayıp veya şiddetli hastalık) geçişler olmak üzere iki grupta ele almıştır. Bu tür geçişler, yaşam süresi boyunca meydana gelerek, genellikle gelişimsel değişim için doğrudan itici bir güç görevi görmektedir (Bronfenbrenner 1986). Alanyazında, boşanmanın çocuklar üzerindeki etkilerinin boylamsal araştırmalar yoluyla incelendiği dikkat çekmektedir (Wallerstein ve Kelly 1980, Cherlin ve ark. 1991, Amato ve ark. 2009). Öngider (2013), çocukluk dönemlerinde ebeveynlerin boşanmasına şahit olan çocukların; yetişkinlik yaşantıları boyunca daha çok sorun yaşadıklarını ve ebeveynleri boşanmış çocukların, kendi evliliklerini de yüksek oranla boşanmayla 
sonuçlandırdığını belirtmektedir. Boşanma sırası ve sonrası meydana gelen çatışmalar, genellikle boşanmadan iki ile üç yıl sonrasında azalmaya başlasa da bazı ebeveynler, bu çatışmaları uzun yıllar devam ettirebilmektedir (Moné ve Biringen 2012). Ebeveynler arasında devam eden çatışmalara maruz kalan çocuklar; sosyal, duygusal ve psikolojik açıdan olumsuz olarak etkilenebilmektedir (Johnston 1994, Öngider 2013, Bilici 2014, Karadağ ve Özdemir 2020). Yapılan araştırmalar, boşanmanın çocuklar üzerindeki olumsuz etkilerinin ilk yıl içerisinde zirve yaptığını, boşanmadan iki yıl sonra ise ilişkilerin daha durağan hale geldiğini göstermektedir (Santrock 2014). Ancak, ebeveyn yabancılaşmasının etkilerinin, yabancılaşma düzeyine bağlı olarak farklılık gösterdiği; orta ve ağır düzeydeki yabancılaşma olgularında çocukların, hedefteki ebeveyniyle ilişki kurmayı tamamen reddettiği dikkate alındığında, zamanla birlikte yabancılaşmanın olumsuz etkilerinin artacağı düşünülmektedir. $\mathrm{Bu}$ doğrultuda bu bölümde odak, zaman içerisinde ebeveyne yabancılaşmanın birey üzerindeki etkileri ve hedefteki ebeveynle yeniden ilişki kurmaya başlama olacaktır.

Ebeveyn yabancılaşmasının, çocuklar başta olmak üzere tüm aile sistemi üzerindeki etkisi çok büyüktür (Harman ve ark.2019). Ebeveyne yabancılaşan çocuklar, yabancılaşmışolmayan çocuklardan daha fazla içselleştirme ve dişsallaştırma problemleri yaşamaktadır (Johnston ve ark. 2005, Geniş ve ark. 2019). Yabancılaşmı̧̧ çocuklar, genellikle uzun süre boyunca hedefteki ebeveyniyle görüşmemektedir. Çocukken yabancılaşan yetişkinler üzerine yapılan çalışmalarda, ebeveyn yabancılaşmasının uzun süreli etkilerinin olduğu belirtilmektedir (Baker 2005, Baker ve Verrocchio 2013). Çocukken yabancılaşma yaşayan yetişkinlerle yabancılaşmanın uzun süreli etkilerinin incelendiği araştırmalarda, katılımcıların çoğunda, düşük benlik saygısı, depresyon, madde bağımlılı̆̆ı, kendine ve başkasına güven eksikliği, kendi çocuğuna karşı yabancılaşma ve boşanma gibi problemler yaşandığı belirtilmektedir (Baker 2005, Ben-Ami ve Baker 2012). Bu bireyler ayrıca korku ve fobiler geliştirebilmekte, bağlanma problemleri ve çocuklarıly yetişkin olarak iletişimlerinde sorun yaşamaktadır (Aloia ve Strutzenberg 2019). Alanyazında, çocukluk döneminde ebeveyne yabancılaşma geliştiren bireylerin zaman geçtikçe yabancılaştırıldığı ebeveyniyle yeniden ilişki kurmaya başlayabildiği de belirtilmektedir (Baker 2005, Rand ve Rand 2006). Hafif düzeyde yabancılaşma geliştiren ve daha öncesinde suçlama ve düşmanlıkla karşılaşmayan çocuklar, yabancılaştığı ebeveyniyle çok hızlı bir şekilde yeniden ilişki kurabilmektedir. Orta düzey yabancılaşma olgularında çocukların yabancılaştığı ebeveyniyle yeniden ilişki kurabilmesi hafif düzeye göre daha azdır. Bu olgularda, yeniden ilişkiyi başlatan en önemli faktör yaşam olaylarıdır. Ağır düzey yabancılaşma olgularında çocukların yabancılaştığı ebeveynleriyle yeniden ilişki kurabilmesi pek mümkün olmamaktadır. Ancak, bazı olgularda yabancılaşan çocukların hedefteki ebeveyniyle eninde sonunda uzlaşabildiği ve bu oranın yaklaşık olarak \%10 olduğu belirtilmektedir (Torun 2017).

Tüm bu bilgiler doğrultusunda, kronosistem düzeyinde, ebeveyn yabancılaşmasının çocuklar üzerindeki olumsuz etkilerinin zamanla birlikte artabileceği ancak bazı durumlarda çocukların yabancılaştığı ebeveynleriyle yeniden uzlaşarak ilişki kurmaya başlayabildiği ifade edilebilir. $\mathrm{Bu}$ süreçte, yabancılaştıran ebeveynlerin yabancılaşma durumu karşısında aktif yaklaşımlar ve müdahalelerde bulunarak çocuklarıyla ilişki kurma çabasına devam 
etmesi gerektiği ve pozitif ilişki yaklaşımlarının bu süreci olumlu yönde etkileyebileceği düşünülmektedir.

\section{Sonuç}

Çatışmalı boşanma sürecinde ebeveynlerden birinin; öfke/kızgınlık hissiyle çocuklarının diğer ebeveyniyle kişisel görüşme haklarını engellemeye çalıştığı, sözleri, davranışları ve tutumlarıyla diğer ebeveyni kötülediği durumlarda çocuklar, hedefteki ebeveyne yabancılaşma riski ile karşı karşıya kalabilmektedir. Tarihsel süreçte, ebeveyne yabancılaşma kavramı, farklı yazarlar tarafından çeşitli isimlerle tanımlanmış olsa da günümüz araştırmacıları tarafından terminolojik açıdan ebeveyn yabancılaşması kullanımının tercih edildiği görülmektedir. Bilimsel açıdan kavramın geçerliği ve güvenirliği, hukuk alanında kullanımı konusundaki tartışma konularına eş zamanlı olarak yapılan bilimsel araştırmalar, ebeveyn yabancılaşmasının birçok farklı sürecin birbiriyle olan etkileşimi sonucu olarak ortaya çıktığını göstermektedir. Bu bağlamda, ebeveyn yabancılaşması sürecindeki çok faktörlü ve dinamik yapı ekolojik sistem yaklaşımı perspektifiyle sunularak her bir sistem düzeyinde çocukların ebeveyn yabancılaşmasını nasıl ve ne şekilde deneyimlediği genel olarak gözden geçirilmiştir.

Mikrosistem düzeyinde, yabancılaştıran ebeveynin ve akrabaların çocuk ile kurduğu ilişki örüntülerinin çocuğun yabancılaşma düzeyi üzerinde etkili olduğu belirtilebilir. Bu süreçte çocuğun direncine karşı hedefteki ebeveynin iletişim kurmak için çaba göstermesi durumunun, uzlaşma ve yeniden ilişki kurma açısından oldukça önemli olduğu ifade edilebilir. Bu doğrultuda mikro düzeyde, boşanma süresince aile üyelerinin güçlü ve zayıf yönlerinin tespit edilmesi, çocuklar için risk oluşturabilecek durumların değerlendirilmesi ve ailelerin gereksinimleri doğrultusunda çocuk odaklı danışmanlık desteği alması önerilmektedir.

Mezosistem düzeyinde, yabancılaştıran ebeveynin çocuğun okulundaki personellerle koalisyon kurarak çocuk üzerindeki etkisini artırabileceği ve hedefteki ebeveynin çocuktan haber almasını önlemek amacıyla çeşitli girişimlerde bulunabileceği görülmektedir. Ev ortamında sürekli olarak yabancılaştırma girişimleriyle karşılaşması ve okul ortamında da hedefteki ebeveyniyle görüşmemesine yönelik alınan tedbirler; çocuğun yabancılaştıran ebeveynin ifadelerinin doğruluğuna olan inancını güçlendirebilmektedir. Bu durum, çocuğun akademik, sosyal ve duygusal açıdan problemler yaşamasını da beraberinde getirmektedir. Bu doğrultuda mezo düzeyde, eğitim ve öğretim ortamlarında yer alan eğitimcilerin boşanma olgularıyla sıklıkla karşılaşabileceği düşünülmekte olup boşanmaya uyum, boşanmanın çocuklar üzerine etkileri, ebeveyn yabancılaşması gibi konularda okullarda hizmet içi eğitimlerin yapılabilmesi önerilmektedir.

Ekzosistem düzeyinde, boşanma davaları sırasında nihai karar vericilerin hukuk alanında çalışan profesyoneller olduğu dikkate alındığında, yabancılaştıran ebeveynin hedefteki ebeveyne yönelik ithamlarının değerlendirilmesi gerektiği, alınan kararların çocuğun gelecekteki yaşantısını şekillendirme noktasında önemli bir etkiye sahip olduğu belirtilebilir. Hakimlerin özellikle boşanma ve velayet davaları sırasında ebeveyn yabancılaşması olgularıyla karşılaşabileceğini dikkate alarak çocukla çalışan profesyonellerin görüşünü de 
almaları ve boşanma sonrasında sürecin kısa ve uzun süreli olarak takip edilmesi gerektiği düşünülmektedir. Bu doğrultuda ekzo düzeyde, sahada çalışan ve doğrudan ya da dolaylı olarak çocukla etkileşim içerisinde olan profesyonellerin (hakim, savc1, bilirkişilik yapan profesyoneller, vb.) ebeveyn yabancılaşması hakkında bilgi ve farkındalık düzeyini artırmak amacıyla hizmet içi eğitimlerin düzenlenmesi, çocukları yabancılaşmanın etkilerinden koruyabilmek amacıyla çocukların gelişimsel özellikleri dikkate alınarak müdahale programlarının geliştirilebilmesi ve bu programların aktif bir şekilde uygulanmasının sağlanması önemli olacaktır.

Makrosistem düzeyinde, ebeveyn yabancılaşmasının oluşumu ve çözümüne yönelik doğru bilinen yanlışlar ele alınmış olup yabancılaşmaya yönelik mitlerin toplumsal yapı üzerine yansımalarının olumsuz yönde olacağı düşünülmektedir. Bu doğrultuda, ebeveyn yabancılaşmasına yönelik makro düzeyde medya aracılığıyla toplumu bilgilendirme ve farkındalık çalışmalarının yapılması ve hukuki açıdan boşanma sürecinde çocukları koruyucu politikaların geliştirilebilmesi önerilmektedir.

Kronosistem düzeyinde, ebeveyn yabancılaşmasının olumsuz etkilerinin zamanla artabileceği görülmekle birlikte, hedefteki ebeveynle yeniden ilişki kurabilmenin mümkün olduğu ancak yabancılaşma düzeyi şiddetinin uzlaşmayı belirlediği ifade edilebilir. Bu süreçte, hedefteki ebeveynlerin yabancılaşma durumu karşısında sürekli olarak pozitif yönde aktif yaklaşımlar sergileyerek çocuklarıyla ilişki kurmaya devam etmesinin oldukça önemli olduğu belirtilebilir. Bu doğrultuda, bilinçli veya bilinçsiz bir biçimde yabancılaştırma stratejileri kullanarak çocuklarını bu sürece dahil eden yabancılaştıran ebeveynlerin; çocukları üzerindeki etkilerinin yıkıcı olduğunu fark edebilmelerini sağlamak üzere terapötik açıdan desteklenmesinin önemli olacağı düşünülmektedir. Alanyazında ebeveyne yabancılaşmanın uzun süreli etkilerine yönelik çalışmaların sınırlı olduğu görülmekte olup gerekli müdahale programlarının da geliştirilmesinde kanıt temelli çalışmalar yapılabilmesi için bu konuda daha fazla nitel ve nicel araştırmaya ihtiyaç olduğu sonucuna ulaşılabilir.

\section{Kaynaklar}

Aloia LS, Strutzenberg C (2019) Parent-child communication apprehension: The role of parental alienation and self-esteem. Communication Reports, 32:1-14.

Amato PR, Meyers CE, Emery RE (2009) Changes in nonresident father-child contact from 1976 to 2002. Fam Relat, 58: 41-53.

Aydın 0, Baran G (2010) Toplumsal değişme sürecinde evlenme ve boşanma. Toplum ve Sosyal Hizmet, 21:117-126.

Baker AJ (2005) The long-term effects of parental alienation on adult children: A qualitative research study. Am J Fam Ther, 33:289302.

Baker AJ (2006) Patterns of parental alienation syndrome: A qualitative study of adults who were alienated from a parent as a child. Am J Fam Ther, 34:63-78.

Baker AJ, Brassard MR (2013) Adolescents caught in parental loyalty conflicts. J Divorce Remarriage, 54:393-413.

Baker AJ, Darnall D (2006) Behaviors and strategies employed in parental alienation: A survey of parental experiences. J Divorce Remarriage, 45:97-124.

Baker AJ, Fine P (2008) Beyond the high road: Responding to 17 parental alienation strategies without compromising your morals or harming your child. http://www. Amyjlbaker.com (Accessed 10.01.2021).

Baker AJL, \& Ben-Ami N (2011) To turn a child against a parent is to turn a child against himself: the direct and indirect effects of exposure to parental alienation strategies on self-esteem and well-being. J Divorce Remarriage, 52:472-489. 
Baker AJL, Verrocchio MC (2013) Italian college student-reported childhood exposure to parental alienation: Correlates with wellbeing. J Divorce Remarriage, 54:609-628.

Bala N, Hunt S, McCarney C (2010) Parental alienation: Canadian court cases 1989 2008. Fam Court Rev, 48:164-179.

Balmer S, Matthewson M, Haines J (2018) Parental alienation: Targeted parent perspective. Aust J Psychol, 70:91-99.

Beiner SF, Lowenstein L, Worenklein A, Sauber SR (2014) Grandparents' rights: Psychological and legal perspectives. Am J Fam Ther, 42:114-126.

Ben-Ami N, Baker AJ (2012) The long-term correlates of childhood exposure to parental alienation on adult self-sufficiency and wellbeing. Am J Fam Ther, 40:169-183.

Bernet W (2008) Parental alienation disorder and DSM-V. Am J Fam Ther, 36:349-366.

Bernet W (2015) Children of high-conflict divorce face many challenges. Psychiatr Times, 32(10):9.

Bernet W, Gregory N, Reay KM, Rohner RP (2018) An objective measure of splitting in parental alienation: The parental acceptancerejection questionnaire. J Forensic Sci, 63:776-783.

Bernet W, Gregory N, Rohner RP, Reay KM (2020) Measuring the difference between parental alienation and parental estrangement: The PARQ-Gap. J Forensic Sci, 65:1225-1234.

Bernet W, Rohner RP, Reay M (2020) Rejecting the rejection of parental alienation: Comment on Mercer (2021). J Fam Trauma Child Custody Child Dev, doi: 10.1080/26904586.2020.1856752.

Bernet W, von Boch-Galhau W, Baker AJ, Morrison SL (2010) Parental alienation, DSM-V, and ICD-11. Am J Fam Ther, 38:76-187.

Bernet W, Wamboldt MZ, Narrow WE (2016) Child affected by parental relationship distress. J Am Acad Child Adolesc Psychiatry, 55:571-579.

Betancourt TS, Khan KT (2008) The mental health of children affected by armed conflict: protective processes and pathways to resilience. Int Rev Psychiatry, 20:317-328.

Bilici AB (2014) Boşanma sürecinin çocuklar üzerindeki psiko-sosyal etkileri. C.ü. Illahiyat Fakültesi Dergisi, 18:79-110.

Bolhari J, RamezanZadeh F, Abedininia N, Naghizadeh MM, Pahlavani H, Saberi M (2012) The survey of divorce incidence in divorce applicants in Tehran. J Family Reprod Health, 6:129-137.

Bow JN, Gould JW, Flens JR (2009) Examining parental alienation in child custody cases: A survey of mental health and legal professionals. Am J Fam Ther, 37:127-145.

Braver S, Lamb M (2018) Shared parenting after parental separation: the views of 12 experts. J Divorce Remarriage, 1-16.

Bronfenbrenner U (1979) The Ecology of Human Development. London, Harvard University Press.

Bronfenbrenner U (1986) Ecology of the family as a context for human development: Research perspectives. Dev Psychol, 22:723-742. Cartwright GF (1993) Expanding the parameters of parental alienation syndrome. Am J Fam Ther, 21:205-215.

Cherlin AJ, Jr Furstenberg FF, Chase-Lansdale L, Kiernan KE, Robins PK, Morrison DR, et al. (1991) Longitudinal studies of effects of divorce on children in Great Britain and the United States. Science, 252:1386-1389.

Clarkson H, Clarkson D (2008) Confusion and controversy in parental alienation. J Soc Welf Fam Law, 29:265-275.

Clawar SS, Rivlin BV (1991) Children Held Hostage: Dealing with Programmed and Brainwashed Children. Chicago, American Bar Association Press.

Clemente M, Padilla-Racero D (2016) When courts accept what science rejects: Custody issues concerning the alleged "parental alienation syndrome". J Child Custody, 13:126-133.

Cummings EM, Davies P (1994) Children and Marital Conflict: The Impact of Family Dispute and Resolution. New York, Guilford Press. Darnall D (2010) Beyond Divorce Casualties: Reunifying The Alienated Family. New York, Taylor Trade Publishing. Darnall D (2011) The psychosocial treatment of parental alienation. Child Adolesc Psychiatr Clin N Am, 20:479-494.

Doğan A (2010) Ekolojik sistemler kuramı çerçevesinde akran zorbalığının incelenmesi. Çocuk ve Gençlik Ruh Sağlığı Dergisi, 17:149-162. Doğan C (1998) Türkiye'de boşanma sorununun sosyolojik ve istatistiki açıdan değerlendirilmesi Sosyoloji Konferansları, 25:59-69.

Drozd L, Saini M, Olesen N (2016) Parenting Plan Evaluations: Applied Research for The Family Court, 2nd ed. Oxford, Oxford University Press.

Drozd LM, Olesen NW (2004) Is it abuse, alienation, and/or estrangement? A decision tree. J Child Custody, 1:65-106.

Eliasa El (2012) Counsellor roles on students' lifelong learning understanding (A psychological study based on ecological system theory). Procedia Soc Behav Sci, 46:5703-5706. 
Emery RE (2011) Renegotiating Family Relationships: Divorce, Child Custody, and Mediation, 2nd ed. New York, Guilford Press. Erdim L, Ergün A (2016) Boşanmanın ebeveyn ve çocuk üzerindeki etkileri. Sağlık Bilimleri ve Meslekleri Dergisi, 3:78-84.

Erdoğan E (2014) Ebeveyne yabancılaşma sendromu örnek raporlamaları. http://www.babac-der.org.tr/wp-content/ uploads/2014/01/erkut-erdogan-eys-ornek-raporlar.pdf (Accessed 11.01.2021).

Farkas MM (2011) An introduction to parental alienation syndrome. J Psychosoc Nurs Ment Health Serv 49(4):20-26.

Fidler BJ, Bala N, Saini MA (2013) Children Who Resist Post-Separation Parental Contact: A Differential Approach for Legal and Mental Health Professionals. New York, Oxford University Press.

Friedlander S, Walters MG (2010) When a child rejects a parent: Tailoring the intervention to fit the problem. Fam Court Rev, 48:98-111. Garber BD (2020) Dynamics, not diagnoses. Fam Court Rev, 58:368-370.

Gardner RA (1985) Recent trends in divorce and custody litigation. Academy Forum, 29(2):3-7.

Gardner RA (1992) True and False Accusations of Child Sex Abuse. Cresskill NJ, Creative Therapeutics.

Gardner RA (1998) The Parental Alienation Syndrome: A Guide for Mental Health and Legal Professionals, 2nd ed. Cresskill NJ, Creative Therapeutics.

Gardner RA (2002) Parental alienation syndrome vs. parental alienation: Which diagnosis should evaluators use in child-custody disputes? Am J Fam Ther, 30:93-115.

Gardner RA (2004a) Commentary on Kelly and Johnston's "The alienated child: A reformulation of parental alienation syndrome". Fam Court Rev, 42:611-621.

Gardner RA (2004b) The relationship between the parental alienation syndrome (PAS) and the false memory syndrome (FMS). Am J Fam Ther, 32:79-99.

Geniş M, Toker B, Şakiroğlu, M. (2019) Boşanmanın çocuklara etkisi, çocuğa söylenmesi ve ebeveyn yabancılaşması derleme çalışması. Adnan Menderes Üniversitesi Sağlık Bilimleri Fakültesi Dergisi, 3:190-199.

Girdner LK (1985) Stategies of conflict: Custody litigation in the United States. J Divorce, 9:1-15.

Goldin DS, Salani D (2020) Parental alienation syndrome: What health care providers need to know. J Nurse Pract, 16:344-348.

Gordon RM, Stoffey R, Bottinelli J (2008) MMPI-2 Findings of primitive defenses in alienating parents. Am J Fam Ther, 36:211-228.

Gregory Öngider N (2016) Boşanma mı yoksa çocuk için evliliği sürdürmek mi? Çocuğun psikolojik uyumu açııından önemli bir soru. Psikiyatride Güncel Yaklaşımlar, 8:275-289.

Güler G (2017) Ebeveyn yabancılaştırma sendromu ve boşanma. Türkiye Klinikleri J Child Psychiatry-Special Topics, 3(3):225-228.

Haines J, Matthewson M, Turnbull M (2019) Understanding and Managing Parental Alienation: A Guide to Assessment and Intervention. United Kingdom, Routledge.

Härkönen U (2007) Bronfenbrenner's ecological theory for students and the audience. V. International Conference "Person. Color. Nature. Music", 17-21 0ctober 2007, Daugavpils University, Daugavpils, Latvia.

Harman JJ, Bernet W, Harman J (2019) Parental alienation: The blossoming of a field of study. Curr Dir Psychol Sci, 28:212-217.

Hetherington EM, Kelly J (2002) For Better or for Worse: Divorce Reconsidered. New York, W.W. Norton.

Johnston J, Roseby V, Kuehnle K (2009) In the Name of the Child: A Developmental Approach to Understanding and Helping Children of Conflicted and Violent Divorce, $2^{\text {nd }}$ ed. New York, Springer Publishing.

Johnston JR (1994) High-conflict divorce. Future Child, 4:165-182.

Johnston JR (2003) Parental alignments and rejection: An empirical study of alienation in children of divorce. J Am Acad Psychiatry Law, 31:158-170.

Johnston JR, Lee S, Olesen NW, Walters MG (2005) Allegations and substantiations of abuse in custody-disputing families. Fam Court Rev, 43:283-294.

Johnston JR, Sullivan MJ (2020) Parental alienation: In search of common ground for a more differentiated theory. Fam Court Rev, 58:270-292.

Johnston JR, Walters MG, Olesen NW (2005) Is it alienating parenting, role reversal or child abuse? A study of children's rejection of a parent in child custody disputes. Journal of Emotional Abuse, 5:191-218.

Kaganas F, Piper C (2020) Grandparent contact: another presumption?. J Soc Welf Fam Law 42:176-203.

Karadağ F, Özdemir DF (2020) Çekişmeli boşanma/velayet sürecinde aile mahkemelerinden üniversite hastanesine gönderilen olguların değerlendirilmesi. Klinik Psikiyatri Dergisi, 24; doi: 10.5505/kpd.2020.76259. 
Karataş E (2019) Boşanmış aile çocuklarındaki uyum problemleri: Ortak ebeveynlik açısından bir inceleme (Uzmanlık tezi). İstanbul, İstanbul Üniversitesi.

Kayma Güneş D (2007) Boşanma sürecindeki eşlerin aile içi ilişkileri ile problem çözme becerileri arasındaki ilişkinin belirlenmesi (Uzmanlık tezi). Ankara, Hacettepe Üniversitesi.

Kelly JB (2007) Children's living arrangements following separation and divorce: Insights from empirical and clinical research. Fam Process, 46:35-52.

Kelly JB, Johnston JR (2001) The alienated child: A reformulation of parental alienation syndrome. Fam Court Rev, 39:249-266.

Kırc GS, Cömert HSY, Özer E (2017) Anne-çocuk cinayetleri Medea Kompleksi. The Bulletin of Legal Medicine, 22:130-133.

Koçyıldırım G (2010) Sosyal hizmet bakış açısıyla çocuk teslimine ve çocukla kişisel ilişki kurulmasına dair ilamların icrası uygulamaları (Uzmanlık tezi). Ankara, Hacettepe Üniversitesi.

Lee-Maturana S, Matthewson M, Dwan C, Norris K (2018). Characteristics and experiences of targeted parents of parental alienation from their own perspective: A systematic literature review. Aust J Psychol, 71: 83-91.

Lowenstein LF (1998) Parent alienation syndrome: What the legal profession should know. Med Leg J, 66:151-161.

Lowenstein LF (1999) The psychological effect and treatment of parental alienation Syndrome. Justice of the Peace, 163:47-50.

Lowenstein LF (2013) Is the concept of parental alienation a meaningful one? J Divorce Remarriage, 54: 658-667.

Maccoby EE, Mnookin RH (1992) Dividing the Child: Social and Legal Dilemmas of Custody. Cambridge, Harvard University Press.

Marchetti D, Verrocchio MC (2017) Intervention in cases of parental alienation: A systematic review of the literature. Rivista Interdisciplinare, 19:67-83.

Marques TM, Narciso I, Ferreira LC (2020) Empirical research on parental alienation: A descriptive literature review. Child Youth Serv Rev, 119:1-55.

Meier JS (2009) A historical perspective on parental alienation syndrome and parental alienation. J Child Custody, 6: 232-257.

Milchman MS, Geffner R, Meier JS (2020) Ideology and rhetoric replace science and reason in some parental alienation literature and advocacy: A critique. Fam Court Rev, 58:340-361.

Moné JG, Biringen Z (2012) Assessing parental alienation: Empirical assessment of college students' recollections of parental alienation during their childhoods. J Divorce Remarriage, 53:157-177.

Ordway AM, Moore RO, Casasnovas AF, Asplund NR (2020). Understanding vicarious trauma, burnout, and compassion fatigue in high-conflict divorce. Fam J Alex Va, 28:187-193.

Öngider N (2013) Boşanmanın çocuk üzerindeki etkileri. Psikiyatride Güncel Yaklaşımlar, 5(2):140-161.

Vanderbilt University (2020) Parental Alienation Database. https://ckm.vumc.org/pasg/citation-manager (Accessed 15.01.2021).

Pepiton MB, Alvis LJ, Allen K, Logid, G (2012) Is Parental alienation disorder a valid concept? Not according to scientific evidence. A review of parental alienation, DSM-5 and ICD-11 by William Bernet. J Child Sex Abus, 21:244-253.

Pines AM, Gat H, TalY (2002) Gender differences in content and style of argument between couples during divorce mediation. Conflict Resolution Quarterly, 20:23-50.

Polak S, Saini M (2015) Children resisting contact with a parent postseparation: Assessing this phenomenon using an ecological systems framework. J Divorce Remarriage, 56: 220-247.

Rand DC, Rand R (2006) Factors affecting reconciliation between the child and target parent. In The International Handbook of Parental Alienation Syndrome: Conceptual, Clinical and Legal Considerations (Eds RA Gardner, SR Sauber, D Lorandos):163-176. Springfield IL, Charles C. Thomas.

Reich W (1949). Character-Analysis, 3nd ed. New York, Farrar Straus Giroux.

Resmi Gazete (1982) Türkiye Cumhuriyeti Anayasası. Ankara, TC Başbakanlık.

Rueda CA (2004) An inter-rater reliability study of parental alienation syndrome. Am J Fam Ther, 32(5): 391-403.

Santrock JW (2014) Yaşam Boyu Gelişim (Çeviri Ed. G. Yüksel) Ankara, Nobel Akademik Yayıncılık.

Sîrbu AG, Vintilă M, Tisu L, Ștefănuț AM, Tudorel, 0l, Măguran B, Toma RA (2021) Parental alienation-development and validation of a behavioral anchor scale. Sustainability, 13(316):1-18.

Sher L (2015) Parental alienation and suicide in men. Psychiatr Danub, 27:288-289.

Steinberger C (2006) Father? What father? Parental alienation and its effect on children. Law Guardian Reporter, 22(3):1-18.

Şen B (2015) Boşanma Arabuluculuğu. Ankara, Nobel Yayıncilık. 
Tavares A, Crespo C, Ribeiro MT (2020) Psychological adaptation and beliefs in targeted parents: A study in the context of parental alienation. J Child Fam Stud, 29:2281-2289.

Tein JY, Sandler IN, Zautra AJ (2000) Stressful life events, psychological distress, coping, and parenting of divorced mothers: A longitudinal study. J Fam Psychol, 14:27-41.

Templer K, Matthewson M, Haines J, Cox G (2016) Recommendations for best practice in response to parental alienation: Findings from a systematic review. J Fam Ther, 39:103-122.

Torun F (2011) Ebeveyn yabancılaştırma sendromu. Psikiyatride Güncel Yaklaşımlar, 3:466-482.

Torun F (2017) Ebeveyne Yabancılaşma Sendromu. Ankara, Psikonet Yayınları.

TÜiK (2019) Evlenme ve Boşanma İstatistikleri. https://data.tuik.gov.tr/Bulten/Index?p=Evlenme-ve-Bosanma-Istatistikleri-2019-33708 (Accessed 12.12.2020).

Ulutürk, S. (2019). 11-18 yaş arası boşanmış aile çocuklarııın ve boşanmamış aile çocuklarııın ebeveyn yabancılaştırma sendromu ve davranış sorunlarının karşıllaşıırmalı olarak incelenmesi (Uzmanlık tezi). İstanbul, ístanbul Aydın Üniversitesi.

Vassiliou D, Cartwright GF (2001) The lost parents' perspective on parental alienation syndrome. Am J Fam Ther, 29:181-191.

Verrocchio MC, Marchetti D, Carrozzino D, Compare A, Fulcheri M (2019). Depression and quality of life in adults perceiving exposure to parental alienation behaviors. Health Qual Life Outcomes, 17:14.

Viljoen M, van Rensburg E (2014) Exploring the lived experiences of psychologists working with parental alienation syndrome. J Divorce Remarriage, 55:253-275.

von Boch-Galhau W (2018) Parental Alienation (Syndrome)-A serious form of psychological child abuse. Ment Health Fam Med, 14:725-739.

Walker LE, Brantley KL, Rigsbee JA (2004) A critical analysis of parental alienation syndrome and its admissibility in the family court. J Child Custody, 1:47-74.

Walker LE, Shapiro DL (2010) Parental alienation disorder: Why label children with a mental diagnosis? J Child Custody, 7:266-286.

Wallerstein JS, Kelly JB (1976) The effects of parental divorce: experiences of the child in later latency. Am J Orthopsychiatry, 46:256269.

Wallerstein JS, Kelly JB (1980) Effects of divorce on the visiting father-child relationship. Am J Psychiatry, 137:1534-1539.

Warshak RA (2003) Bringing sense to parental alienation: A look at the disputes and the evidence. Fam Law Q, 37:273-301.

Warshak, RA (2015) Ten parental alienation fallacies that compromise decisions in court and in therapy. Prof Psychol Res Pr, 46:235249.

Warshak RA (2020) When evaluators get it wrong: False positive IDs and parental alienation. Psychol Public Policy Law, 26:54-68.

Yıldııı Ş, Işıkhan V (2018) Çocuk evinde kalan çocukların sosyalleşme sürecindeki ilişkilerin değerlendirilmesi. Toplum ve Sosyal Hizmet, 29:46-70.

Yörükoğlu A (2012) Çocuk Ruh Sağlığı, 32nd ed. İstanbul, Özgür Yayınevi.

Yvanna Aires Gadelha S (2016) Medea's children and the parental alienation syndrome. Psicologia USP, 27:482-491.

Zafar N, Kausar R (2014) Emotional and social problems in divorced and married women. FWU Journal of Social Sciences, 8:31-35.

Ziyalar N, Altuntaş G (2018) Parental alienation- father as a rejected parent. The Bulletin of Legal Medicine, 23:25-36.

Yazarların Katkıları: Yazarlar çalışmaya önemli bir bilimsel katkı sağladıklarını ve makalenin hazırlanmasında veya gözden geçirilmesinde yardımcı olduklarııı kabul etmişlerdirr.

Danışman Değerlendirmesi: Dış bağımsız.

Çıkar Çatış̧ması: Yazarlar çıar çatışması bildirmemiş̧ii.

Finansal Destek: Yazarlar bu çalışma için finansal destek almadığııı beyan etmiştir.

Authors Contributions: The authors attest that they have made an important scientific contribution to the study and have assisted with the drafting or revising of the manuscript.

Peer-review: Externally peer-reviewed.

Conflict of Interest: No conflict of interest was declared by the authors.

Financial Disclosure: The authors declared that this study has received no financial support. 